\title{
Videofelsefe Manifestosu
}

\author{
Ayşe USLU*
}

\section{Özet}

Bu yazı, felsefe yapmanın söz merkezli geleneksel yöntemlerinin bir eleştirisini içermekte ve felsefi düşünceyi sözel imgelerin ötesine taşıyarak, duyusal ve duygulanımsal imajlarn felsefe yapmanın bir yolu olarak önermektedir. Henri Bergson'un zaman felsefesinden yola çıkarak, dünyanın bedenden ayrı bir zihin tahayyülünün ürettiği imajlar bütünü olmaktan çok, imaj akışlarından, yani zamanın sıkışıp gevşeme hareketlerinden ibaret olduğu kabul edilirse, ışı̆̆ın bir taşıyıcı üzerindeki izinden çok "ışı̆̆ın ifadesi" olarak videonun, maddi ve zihinsel sentezler gibi işleyerek zamanı kristalleştirdiği, yani doğrudan varliğın ifadesi olduğu kabul edilebilir. Bu bağlamda, Maurizio Lazzarato'nun deyimiyle video gibi "hafiza ya da zamanı kristalleştirme teknolojileri", algıyı, belleği ve zihinsel emeği taklit eden teknolojilerdir. Bu teorik altyapı çerçevesinde bu çalışma, dijital görselleştirme, kayıt alma ve işleme tekniklerini, sözel imajların sinırlarnın ötesinde duyumsanabilir imajlar yoluyla felsefe yapmanın bir aracı olarak görmeyi önerir. Böylece, felsefenin konu edindiği malzeme ve onun üzerine felsefe yapma yöntemi bir ve aynı şey haline gelerek zamanm imajları olacaktır ve bu yolla felsefe geleceğin yeni düşünce dillerine uyum să̆lama yoluna girecektir. Bu bağlamda, bu metin, felsefe yapmanın geleneksel araç ve yöntemlerini bir eleştiriye tabi tutarak, videoyu felsefe yapmanın yeni bir yolu olarak sunarak, felsefecileri bu konuda tartısmaya davet etmektedir.

Anahtar Kelimeler: Videofelsefe, Zamanın kristalleşmesi, Hafiza teknolojisi, Duygulam, Sine-göz.

ORCID ID : https:/ / orcid.org/ 0000-0002-3144-4195

E-mail : ayse.uslu@nisantasi.edu.tr

DOI: 10.31122/sinefilozofi.682565

Geliş Tarihi - Recieved: 31.01.2020

Kabul Tarihi - Accepted: 23.03.2020 


\title{
The Videophilosophy Manifesto
}

\author{
Ayşe USLU*
}

\begin{abstract}
This article presents a critique of the logocentrism in traditional forms of doing philosophy, and proposes sensory and affective images as ways of doing philosophy by moving philosophical thinking beyond verbal images. With reference to Henri Bergson's philosophy of time, the World is composed of fluxus of images, that is the movements of contraction and loosening of time, and video can be considered to be an expression of light rather than a trace on a trailing surface, and to crystalize time by imitating material and mental synthesis. As Maurizio Lazzarato asserts, video is a technology of memory or crystallization of time, which imitates human perception, memory and mental labor. In this respect, this article proposes to see digital visualisation, recording and processing techniques as tools of doing philosophy through sensory images transcending the limits of verbal images. Thus, the subject and the tool of philosophy can be one and the same material as images of time, thereby which philosophy can adapt to new languages of thought of the future generations.
\end{abstract}

Keywords: Videophilosophy, Time crystallization, Technology of memory, Affect, Kino-glaz.

ORCID ID : https:/ / orcid.org/ 0000-0002-3144-4195

E-mail : ayse.uslu@nisantasi.edu.tr

DOI: 10.31122/sinefilozofi.682565

Geliş Tarihi - Recieved: 31.01.2020

Kabul Tarihi - Accepted: 23.03.2020 


\section{Giriş}

Felsefe, Platon'dan beri kendini yazı teknolojisinin dil ve düşünce üzerinde yarattığ1 etkinin kollarına bırakmış durumdadır. Platon diyaloglarında yazının hafıza üzerinde yarattığı bozucu etkiyi eleştirmiş olsa bile, felsefi metodunu ve aslında düşüncesinin biçimini bu teknolojik gelişimin etkisine açmıştır. Fikirlerin doğdukları kaynağa yani yaşamın hareketine yabancılaşması, olayların temsillerine dönüşerek onlardan kopma hareketi, bu harekete bir kural kazandırmaya çalışan mantıkla da desteklenir. Yazı nasıl artı değeri düzenlemenin peşindeki despotun icadıysa, felsefenin deneyimin kendisinden koparak kazandığı ideal düzen de, temsil-merkezci, yazı-teknolojisinin insan zihni ve düşünme biçimleri üzerinde yarattığı değişimi ve dönüşümü görmezden gelen, artık sadece kendi kendine gönderme yaparak temsil etme çabasında olduğu olaydan kopan ve onun yerine geçen, metinler arası kapalı bir devre halinde yükselen despotik düşüncenin ürünüdür. Bu manifestoda, yazı teknolojisinin miras bıraktığı düşünme ve ifade biçimleriyle felsefe yapan felsefecilere bir çağrıda bulunularak, felsefe yapmanın sözmerkezci formları bilgi üretim sürecini temsiliyetçi formlara indirgemesi nedeniyle eleştirilmiş ve yerine video, bizi kelimelerin ötesinde duyusal ve duyuşsal imgelerle düşünmeye götürecek bir yöntem olarak önerilmiştir. Bu bağlamda, felsefenin varlık "hakkında" olmaktan kurtarılarak, araya temsillerin aracılığını sokmadan bizzat varlığın kendisiyle felsefe yapmanın olanaklı olduğu iddia edilmiştir. Varlığın saf olarak "zaman" ve dijital görüntüleme, kayıt ve işleme sistemlerinin zamanı kristalleştirme teknolojileri olduğu kabul edilirse, felsefenin malzemesinin ve yönteminin bir ve aynı şey olabileceği iddia edilebilir. Henri Bergson'un zaman felsefesinden yola çıkarak, dünyanın bedenden ayrı bir zihin tahayyülünün ürettiği imajlar bütünü olmaktan çok, "birbiriyle karşılaşan, çarpışan, birbirini yansıtan, birleşen ve çözülen" imaj akışlarından, yani zamanın sıkışıp gevşeme hareketlerinden ibaret olduğu kabul edilirse, ışığın bir taşıyıcı üzerindeki izinden çok ışığın ifadesi olarak videonun, Bergson felsefesinde tarif edildiği şeklinde maddi ve zihinsel sentezler gibi işleyerek zamanı kristalleştirdiği, yani doğrudan varlığın (maddenin=1şı ğın=zamanın) ifadesi olduğu kabul edilebilir (Lazzarato, 2016:32). Bu bağlamda, Maurizio Lazzarato'nun (2016) deyimiyle "zamanı kristalleştirme teknolojileri” 1, algıyı, belleği ve zihinsel emeği taklit eden teknolojilerdir. Lazzarato "zamanı kristalleştirme teknolojileri" ifadesindeki, "kristalleşme" terimini, "zaman ve onun sentezleri tematiğini, emeğin zaman, metanın da onun kristalleşmesi olarak tanımlandığı Marksist değer kuramıyla" bağlantısını kurduğu bir düşünsel hattan yararlanarak kullanır (Lazzarato, 2016:7). K. Marks, Kapital'in birinci cildinde, "bir değer olarak meta, kristalleşmiş emektir" tabirini, harcanan zamanla tanımlandığı için uçucu, görünmez bir varlığa sahip olduğunu düşünebileceğimiz emeğin, üretim sürecinin sonucu olarak beliren metada maddeselleştiğini, cisimli hale geldiğini ifade etmek için bu terimi kullanmıştır (Marks, 1976:7-40). Lazzarato için, zamanın kristalleşmesiyle, emeğin kristalleşmesi, yani aslında her ikisinin de maddeselleşmesi, aralarında doğrudan bir geçiş olduğu iddiasıyla benimsenmiştir. Buna göre, zamanı kristalleştirme makineleri artık yalnızca emek zamanını değil, yaşam zamanını da değiştirir ve kapsar (Lazzarato, 2016:7). Yaşam zamanı burada, çağdaş kapitalizmin yaratıcılıklarını kaptığı, sömürdüğü, öznelliğin ve dünyanın üretimine katılan semiyotikler, kuvvetler ve duygular karışımlarından ibaret zamandır. Kristalleşme, maddeselleşme anlamında kullanılır, zamanın, yani Bergson'un eşitliğine dayanarak söylersek enerjinin, maddeselleşmesidir. Video, fotoğraf, sinema ve dijital teknolojiler zamanı sıkıştırma, yoğunlaştırma makineleridir. Bir genellemeyle şunu söyleyebiliriz ki, felsefeciler olarak, felsefenin sözel dille sınırlandırıldığı oldukça rasyonalist 
bir formasyonun ürünleriyiz. Felsefe yapmaya dair genel algımız, düşünme sürecini temsili imgelere sığdırmaktadır. Oysa, gerçekliğin yeniden üretimi olmaktan ziyade, zamanın elektromanyetik dalga akışlarını kontrol etmekten ibaret olan video teknolojisini kullanarak, yani doğrudan zamanın sıkışıp gevşeme hareketlerini kullanarak, gerçekliğin ikincil bir düzeyde temsili olan dilin ötesine geçen imajlarla felsefe yapabiliriz. Bu durum bizi, düşünsel şemalardan çok kuvvetlerle çalışmaya itecektir. Çünkü, nasıl ki yine bir sıkışma ve gevşeme hareketi olarak algımızı oluşturan asıl öğe, bir etkilenebilme ve etkileyebilme yani hissedebilme kapasitesiyse, videoda da ş̧ı̆̆ın maddi sentezinin kaydı bu defa bir canlının eyleme gücü tarafından değil ama bizzat ışığın yani zamanın kuvvetleri arasındaki ilişkiye bağlı olarak ortaya çıkar. İmaj işleme teknolojileri sayesinde de, insan belleğinin işlevine çok benzer şekilde, virtüel olanla edimsel olan yan yana getirilir, üst üste koyulur, iç içe geçirilir ve bir kuvvet ilişkisi içerisine sokulur. Böylece, hafızayla ilişkisi içinde düşünme eylemi, doğal algının lineer düzeninden, kavramların sabitleyici darlığından ve nesnelerden kopuk soyut dünyasından arınarak varlıkla doğrudan bir ilişkiye girer. Gerçeklik ve kavram, görünüş ve gerçeklik arasında bir ayrım yapmadan ortaya koyulacak bir ontolojinin, felsefe yapma biçimimizi değiştirebilme olasılı̆̆ı, üzerinde durmaya değer bir projedir. Bu metin, Lazzarato'nun Bergson felsefesinden yararlanarak ortaya koyduğu video felsefesinin izini takip eder ve bu izleğin ötesinde geleneksel felsefe yapma aracı olan yazı teknolojisini eleştirerek, videoyu kendi başına felsefe yapmanın bir aracı ve yöntemi olarak önerir. Video üzerine felsefe yapmak, videonun felsefesini yapmak ve video aracılığıla felsefe yapmayı birbirinden ayırarak düşünürsek, bu metin üçüncüsüyle ilgilenir ve ikinci başlıkla ilgilenen Lazarato'nun açtığı düşünce düzlemine katkıda bulunmayı hedefler. Bu bağlamda birinci bölümde, felsefe yapmanın yazı teknolojisine dayalı klasik formları zihin ve düşünce üzerindeki etkileri, avantajları ve dezavantajları bakımından tasvir edilmiş; ikinci bölümde, felsefede neden bir dil değişikliğine gidilmesi gerektiği üzerinde durulmuş; üçüncü bölümde ise, video aracılığıyla düşünmenin anlamı, kapsamı ve gerekliliği tartışılmıştır.

\section{Yazı Teknolojisinin Düşünce Üzerindeki Etkisi}

Teknolojinin duyuların ve en nihayetinde insan bilişselliğinin uzantıları olduğu (McLuhan, 1994) ve her türden uzantının, bilişsel sürecin bizzat doğasını değiştirerek dünya algısını baştan sona değiştirdiği düşünüldüğünde, yazının icadından önce sözlü düşünce ve yazı teknolojisiyle gelişen simgesel sistemlerle entegre düşünce arasında, doğasal farklar olduğu söylenebilir. Olayların ve deneyimlerin yazı teknolojisiyle aktarılması, alfabenin icadıyla birlikte farklı bir boyut kazanmıştır. Alfabe, devasa miktarda düşüncenin, sonsuz sayıda kombinasyonda bir araya gelmesini sağlayan bir kodlama sistemini mümkün kılmıştır. Edimsel gerçekliğin düşünsel ideal boyutu ya da Stoacılardan ödünç alarak söylersek "saf bir düşünsel olay" olarak anlamın çoklu evreninin doğmasında ve gerçekliğin yerini almasında bir kodlama sistemi olarak yazı teknolojisinin doğrudan etkisi vardır. Bu etki, sonradan insanın çözümleyici düşünmesini mümkün kılacak ve onu yarattığı dilsel yapıların gerçeklikten daha gerçek olduğunu düşünmeye itecek bir yolculuğun başlangıcı olacaktır. Hali hazırda dilli düşüncenin beraberinde getirdiği düşüncede bölünme ve dolaylama, yazıyla birlikte düşünmenin bir kuralı haline gelir. Gerçekliği yalnızca uzamsal kategorilerle, bölerek, dizgeselliğe vurarak, ölçerek ve çıkarımsal bir mantıkta yorumlama, düşüncenin ancak uzamsal bir varlığa dönüşmesiyle mümkün olmuştur. Bu bize gerçeklik hakkında daha uzun cümleler kurabilme ve akıl yürütebilme imkânı sağlasa da, bizi bir konuşmanın diyaloğa dayalı doğasının anlık olarak sunduğu sağlama yapma olanağından ve düşüncenin sahibine 
geri iade edilebilmesi özgürlüğünden sonsuza kadar koparmıştır. Yazı teknolojisiyle birlikte, düşünce onu konuşanın sesinden kopmuştur (Ong, 1991: 47). Sözlü dil sese bağlıdır fakat yazı teknolojisi, sözü bir yüzeye aktararak mekâna bağlar ve dilin gücünü pekiştirir, fakat aynı zamanda düşüncenin yapısını da değiştirmiş olur. Ses diğer duyular gibi kaydedilebilen bir şey değildir, varlığını yitirirken işitilir, yani sabitleştirmeye karşı koyan bir doğaya sahiptir ve bizim bu durumu yazıyla aştığımız söylenebilir (Ong, 1991: 140). Yavaşlatarak dinleyebilmeyi sağlamıştır yazı. Fakat, olayları temsillere dönüştürme bedeliyle olmuştur bu dönüşüm. İşte bu düşünceyi yavaşlatma imkânı sunan temsiller sayesinde yazı, sözlü düşüncenin yapamayacağı bir şeyi yapar ve analitik değerlendirme yani incelemeyi, düşünmeyi meydana getiren unsurları birbirinden ayırmayı, düşüncenin soyut, dizimsel, sınıflandırıcı ve açıklayıcı bir çözümlemesini mümkün kılar. Sözlü kültürde, bir konu üzerinde uzun boylu düşünmek için biriyle diyalog kurmaya ihtiyaç vardır. Fakat çözümleyici düşünce için bu durum yeterli değildir, çözümleme için geriye dönüp bakmak gerekir, hitap edilen okuyucu kitlesi her daim hayali olarak kalmaya devam edecekse de, çözümleyici düşüncenin sonsuzca dizgesini kurmak ancak yazı teknolojisiyle mümkün hale gelmiştir. Konuşurken girdiğimiz felsefi bir tartışmada, önceki sayfalara dönüp bakamayız. Ya da, akıl yürütmemizde kısa süreli hafızamızın ulaşamayacağı kadar uzak bir öncülü bulup yanlışlayamayız, ancak yazıyla yeni bir uzam kazanmış öncülümüz sayısız önerme sonrasında bile bizi olduğu yerde beklemektedir. Böylece, önermelerinizi bir kitap uzunluğunda kurabilir, öncüllerinizin sayısını sözlü bir anlatının içerebileceğinin ötesine taşıyabilirsiniz. Bütün dünya deneyiminizi, cinslere ve türlere bölerek sınıflandırabilir, bunun bilimini inşa edebilirsiniz yazı sayesinde. Kalabalık ve karmaşık bir fiziksel düzeni, matematiksel hesaba vurarak formüle edebilir, bir evren modeli çıkarabilirsiniz. Fikirlerin art arada gelebilme özelliğinin, düşüncenin doğasına içkin olduğunu sanırız. Oysa, art arda gelmek gibi uzamsal bir nitelik, ancak yazıyla birlikte düşüncenin uzamsal bir varlık kazanmasıyla mümkün olmuştur. Fikirlerin parçalı doğası, genelliği, bu genellikten çıkan soyutluğu, dizimselliği ve sınıflandırıcılığı yazıyla birlikte gelen uzamsallığın mümkün kıldığı özellikleridir. Sözlü kültürde sesin akışkanlar mantığına bağlı kalan düşünce, duygulara, olaylara, edimlere ve konuşmanın performatif doğasına daha yakın durmasına rağmen, konuşulurken gerçekliği değiştirme durumunun her halükârda yine de sınırlı kalan edimsel eşiğinden yazıyla birlikte kurtulmuş ve artık sınırının çizilmesi neredeyse imkânsız virtüel bir boyut kazanmıştır. Felsefe artık peripatetiklerin yürürken yaptığı bir eylem olmaktan çıkacak ve ölülerin fikirleriyle iletişim kurabilmeyi sağlayacak olan bir kayıt sisteminin kurallı oyununa dönüşecektir. Bu sinırsızlığın bedeli, Stoacı deyimiyle bedenli karışımlara indirgenemeyecek olan cisimsiz olayların, yani yaşamsal oluşların, mantıksal sınırları çizilmeden ya da bir sınıflandırmaya tabi tutulmadan anlaşılamayacak olduğu dilsel bir aynalar koridorunda felsefe yapmaya mahkûm olmaktır. Dil konuşulduğu anda, bir şey yaparak gerçekliği değiştirir. Ancak dil, yazıya dönüştüğü anda gerçekliğin yerine geçecek yeni bir gerçeklik düzlemi yaratır. Felsefenin büyük uğraşı, üst üste binmiş gerçeklik katmanları içinde bir düzen aramak mı, yoksa gerçekliği değiştirmek midir?

Yazı teknolojisi dille olan bağımızda derinden bir değişiklik yaratmıştır. Yazı, kelimelerin öncelikle görsel bir boyuta hapsedilmesine, yani onların ancak yazılışlarıyla birlikte düşünülebilmesine neden olmuştur (Ong, 1991). Okuryazar kültürün içine doğmuş biri sözlü kültürün düşünme biçimini anlayamaz. Bizler düşünmenin sadece kelimelerle yapılabilir bir eylem olduğuna ikna olmuş durumdayız. Hatta durup acaba sözel imgeler olmadan, görsel, dokunsal ya da duyuşsal imgelerle düşünmek mümkün müdür sorusu üzerine kitaplar yazıyoruz. Sanki düşünce, duyumsal ve duygulanımsal olandan doğmuyormuş 
gibi, sanki insan onlar olmadan da meramını anlatamıyormuş, eyleyemiyormuş ya da düşünemiyormuş, yani kısaca dünya üzerinde değişiklik yaratamıormuş gibi, onların nereden geldiğini unutuyor ve düşünmeyi kelimelerle yapılan bir eylem olmaya indirgiyoruz. Şimdi, durup kitaplarca anlatmaya çalıştığımız ve laboratuvarlarda deney düzenekleri içinde ölçüp biçtiğimiz, zihnin çalışma mekanizmaları üzerine kuramlar ortaya atıyoruz, ancak bu kuramların neredeyse hepsinin insan zihninin doğasını onun yarattığı teknolojilerin etkisinden azadeymiş gibi, bu etki hesaba katılmadan sanki onların içkin nitelikleriymiş gibi ona mal edilerek ortaya atıldığını fark etmiyoruz. İnsan zihninin bedenden kopuk bir soyutlukta dilsel bir yapıya sahip olduğunu düşünmek (Fodor, 1975), ancak bu dilin yazı teknolojisiyle uğradığ1 dönüşümü hesaba katmamak çağımızın zihin modellerinin içine düştüğü büyük bir çelişkidir. Zihin ve bedeni birbirinden ayrı düşünmenin ve zihni en eski zamanların bal mumu baskı modelinden bugünün bilgisayar modeline dek, ancak canlı kanlı deneyimin soluk bir temsiliyle işleyen bir mekanizmaya benzeterek anlamanın temelinde, düşüncenin yalnızca duyumsamadan kopuk bir kod sistemi biçiminde, berimsel (bilgisayımsal) bir işleyişte oluştuğuna inanmak yatar. Oysa bu inanç, bizzat düşüncenin kendi felsefi soruşturmasında, düşüncenin koşulları ve bu koşulların maddesel dönüşüm tarihi hesaba katılmayarak, olumsallığından uzak bir değerlendirmeye tabi tutulmasının sonucudur. Felsefe, dile olan idealist bakışı nedeniyle kendi kendini tuzağa düşürmüş görünür. İtiraf edelim ki, felsefenin, felsefe yapma koşullarını verili kabul etmesi büyük bir hatadır. Düşünmek eylemi, Rodin'in Düşünen Adam heykelinde canlandırdığı başı iki elinin üzerinde tefekküre dalmış boş bakışlı bir adamın işi olma mertebesine, yazı teknolojisinin, soyut düşünceyi mümkün kılan idelerin uzamsallık kazanmasına izin vermesi ve düşünceyi yalnızca kelimelerle yapılan bir iş haline getirmesiyle mümkün olmuştur. Bu uzamsallaştırma hareketi sayesinde, kelimelerin bir olay, bir eylem olmaktan çok bir şeyi temsil ettiği bir düzenin gelmesiyle, ide ve gerçeklik ayrımını düşüncemize yerleştirecek olan kırılma gerçekleşmiştir. Bu tuzağa ilk düşenin Platon olması bir tesadüf değildir. Bu durum, maddi tarihin kaçınılmaz sonucudur. Ne var ki Platon, idelerin maddesel oluş karşısında rakipsiz tek gerçeklik olma statüsünü talep eden tek filozof olmayacaktır. Felsefe tarihi, kavramların ortaya çıktıkları bedensel karışımlardan ayrı ve daha gerçek olduğunu iddia eden, kelimelerin büyüsüne kapılmış fikir tacirleriyle doludur. Felsefe tarihi boyunca, gerçekliği daha iyi anlayabilmek adına karşı bir hareket olarak, ideleri kaynaklarına geri döndürme, yani bedeni felsefeye dahil etme çabalarını alkışlarla karşılıyoruz. Ancak, içlerinde hiçbiri bu kopuşun kendisinin yine insan elinden çıkma bir teknolojinin yan etkisi olduğunu görememiştir. Bunu görmek için -ilk anlamıla- felsefe yapma dilimizin değişmesini beklemek zorundayı.

Gerçeklikten koparılmış ve ideal bir düşünsel boyutta aşık atma diline muktedir bir zihnin söylediği her söz, sınanmış olsun ya da olmasın gerçeklik hakkında dikkate alınması gereken bir önerme olma statüsüne sahiptir. Yazıda söz alışverişi yoktur, okurken karş1 çıkamazsınız bir fikre. Bir metin doğrudan çürütülemez ve çürütülse bile kitabı değiştirmek için onu yakmanız gerektiği söylenebilir (Ong, 1991). Yazı teknolojisi, hali hazırda kendileri de kuvvetli bir teknoloji olan kelimeleri nesnelere dönüştürmüştür yani sesi nesneleştirmiştir. Bu nesnelerle, yeni ve çok katmanlı hafızalar kurabilmenin yolu açılmıştır. Avantaj gibi görünen bu durum, aynı zamanda cehaletin tek geçer para haline gelmesinin yollarını kolaylaştırmıştır. Sözlü kültürde neyi anımsayabilirsen onu bilirsin. Bilgi birikimin hafızan kadardır. Ancak, yazıyla birlikte kalıcı hale getirilen fikirler her daim yardımına koşar. Fakat, yardımına koşan fikirlerin her zaman sadık kalacağı bir hakikat inancı keyfi bir inşa sürecine bağlıdır. Yalanın dilin doğuşuyla birlikte mümkün olduğu doğru olsa da, onun kurumsallaşması yazı 
teknolojisi sayesinde mümkün olmuştur. Düşünme yazıyla birlikte, konuşmacının konuşma esnasındaki pragmatik çıkarlarından koparak idelerin yani temsillerin birbiriyle olan ilişkilerine bağlanır. Bu düzlemde ideolojik dolgular ve manipülatif yapışkan malzemeler kendilerine uzamsal bir düzlem açarak daha kolay ilerler ve aktarılırlar. Bu sizi bir konuşma esnasında kendi çıkarlarım uğrunda kandırmamdan daha yüksek dereceden bir düzenekle bana inanmaya ikna etmenin araçlarına sahip olmam demektir. Retoriğin başarılarının ötesinde bir zaferdir yazının aldatmacası. Yalanların en büyügüüse, bilen ve bilinen (öznenesne) arasına koyulan mesafedir. Yazıyla birlikte, anlam duruma bağlı olmaktan koparak düşüncenin kurallarına bağlanır. Fikirlerin içinden doğdukları bağlamdan kopması, ancak bu bağın koşul olma niteliğini ve her daim belirleyici bir unsur olarak oluşa katıldığını unutacak kadar düşüncemizin nesnesinden kopuk olduğuna kendimizi ikna etmeyi başardığımızda sorun haline gelir. $\mathrm{O}$ zaman düşünce, bir kendilik ve içsel bir yaşam alanı olarak kendinden menkul bir düzlem haline gelir. Beden üzerine konuşur ama bedenli olduğunu unutur. Maddeyi açıklamak ister ama kendi maddeselliğini hesaba katmaz. Düşüncenin imgesi haline gelir. Düşünce düşünmez, sadece soluk imgelerini üretir. Madde ideden ayriymış da, aralarındaki boşluğu düşüncenin doldurması gerekiyormuş gibi bir izlenime kapılır düşüncenin kendilik yaşamı. Bilgi üretimi, içsel ve dışsal olan arasındaki boşluğu kapatmaya çalışma çabası haline gelecektir. Ve bu onulmaz çaba, her daim öznenin nesneden çok kendini tasviriyle son bulacaktır. Özne gerçekliğin tek referans noktası, tek kaldıracı haline gelir. Bu durumda maddenin oluşu hakkında konuşmak, maddenin madde adına konuşması değil, madde hakkında bedenlenmemiş bir konuşma olarak kalacaktır.

Öznenin kendini abartmasının doğal sonuçlarından biri de, algı mekanizmasının bir yan ürünü olan kronometrik zaman algısının realizmini talep etmesidir. Ölçülebilir zamanın, ona homojen, mutlak ve evrensel bir gerçek olarak görünmesinin, kullandığ1 teknolojinin bir yan etkisi olduğunu görmez. Yazı, düşünceyi kronometrik/ölçülebilir zamana bağlamıştır. Ses konuşmaya bağlı kaldığı sürece, zaman içinde bölünemez bir akış olduğu yerde, yazıya dönüştüğü zaman, süreksiz kesilmelerle sınırlayıcı ve yanıltıcı bir gerçeklik anlayışı yaratır. Dilli düşüncenin ilerleyen, önceli sonralı zaman algısının oluşmasında katkısı olduğu bilinir. Ancak yazı, bu algının düşüncenin bir formu haline gelmesine ve kurumsallaşarak evrenselliğini talep etme güvenini kazanmasına neden olmuştur. Dünyayı öncelik-sonralık ilişkilerine göre düzenleme obsesyonu, yazı teknolojisi sayesinde acısını dindirmiştir. Bu sayede, tam aydınlatılmış, ışık hızı kadar olmasa da insan duyularını aşan hızlarda ilerleyen ve sonu belirsiz bir geleceğe doğru son hizla hareket eden konforlu dünya treninden bir bilet alabildik. Yaşam enerjilerinin sayılabilir rakamlara dönüştürülebilmesi ve böylece meta haline gelebilmesi üzerine kurulu büyük biyopolitik denetim aygıtları mümkün hale gelebildi. Emek zamanının ötesinde yaşam zamanının da sömürülmesi bu sayede mümkün hale gelmiştir. Kapitalist toplumda sorun artık "emek zamanının kristalleşmesi" değil, yaşam zamanının da kodlanabilir hale gelerek metaya dönüşebiliyor olmasıdır. "Makinesel köleliğin" yarattığı mutlak zamanın emperyalizminde, "salt girdiler ve çıtılar, kölelik tarafından işletilen ve yönetilen ekonomik, toplumsal veya iletişim süreçlerinde bir bileşim veya ayrışma noktası meydana getiriyoruz" (Lazzarato, 2015: 26). Kapitalizm, bilinçaltını semiyotik bir istilaya tabi tutar ve bu yolla arzulama üretimini yani öznel zamanı toptan ele geçirir (Guattari, 2011). "Sadece kelimeler imgelerle dolu olduğundan değil, aynı zamanda, bu kelimeler ve imgeleri üreten her türden mekanizmayı da içerdiği için bilinçaltı makineseldir" ve kapitalist köleliğin semiyotik bileşenleri, baskın sınıfların üretimin failleri üzerinde kurdukları iktidarı sağlamlaştırmaları için temel araçları oluşturur (Guattari, 2011:10, 38). Çağımızın kölelik 
düzeni öznelerle değil, öznelliklerin moleküler bileşenlerini bir araya getiren genel bir zamanın kristalleştirici ve aynı zamanda buharlaştırıcı etkisiyle çalışır. Kapitalist makinenin çalışması için, tüm bileşenlere ait zamanın kodlanabilir hale getirecek bir sisteme ihtiyaç vardır ve tüm kodlama sistemlerinin kökeninde yatan yazı teknolojisi köleliğin en eski zamanından beri bu ihtiyacı yerine getirmiştir. Yazı teknolojisi sayesinde sağlamlaştırılan "ulusal dillerin gösteren iktidarı, devletlerin ve kurumlar ağının çok biçimli iktidarıyla iç içe gelişir" (Guattari, 2011:10, 39). Ne toplumsal makineler, ne teknik makineler, ne de arzulama makineleri, gösteren devlet makinelerinin üst-kodlamasından kaçamaz (Guattari, 2011:39). Yazı makinesi, toplumsalı, teknik ve duygulamsal olanı birleştiren bir ağ örerek, "arzu akışlarının semiyotik, makinesel köleliğine" ve "semiyolojik tabi kılma" operasyonlarına hizmet ederek öznellik üretimini her koldan genel bir zamana bağlar2 (Guattari, 2011: 40).

Yazı teknolojisinin düşüncede bir açılım ve ona virtüel bir boyut sağladığı doğrudur. Kelimelerin hareketlilik kazanması, bilincin hareketini de tetiklemiş ve onu edimsel olanın sınırlayıcılığından kurtaracak bir manevra kazandırmıştır. Bilincin, duyusal-motor eylemin erekselliğinden kurtulması, seçim ve yaratma olanaklarını arttıracak bir etki yaratmıştır. Yazı, bilince içinde cisimleştiği gayri maddi bir beden sağlayarak, dikkatini toplama imkanları ve çok detaylı entelektüel işlerde büyük odaklanma ortamları yaratma imkanı sunarak, devasa karmaşı entelektüel yapıların inşa edilebilmesini sağlamıştır. Yazı, oluşu sabitleyebilmenin en kuvvetli anahtarıdır. Temsil etme eyleminin temsiline yani idelere gitmeyi ve onları uzamsal bir şebeke içinde sabitlemeyi sağlamıştır. Sonuç olarak yazı, idelerin cisimsel bir varlık kazanmasıyla zihinsel sentezlerin uzamsallaştırılmasına yaramıştır. Ancak bunun sonucunda, ortaya bölünebilirliğe ve niceliksel farklara dayalı bir düşünce sistemi çıkmıştır. Bilincin özgürlüğüne hizmet etme hevesindeki yazı, bunun karşıllı̆̆ında düşünceye, ikili karşıtlıklar, değilleme mantığı, kronometrik zamansallık ve dizgeselliği hediye etmiştir. Bunun en yakıcı sonucu, en nihayetinde yaşamın sürekliliğinden ve sürekliliğin duyumunu ifade etmekten uzak bir düşünce sistemi olmuştur. Yazı teknolojisi, görünüş ve gerçeklik arasındaki ayrımı gittikçe büyüyen oranda derinleştirmemize yaramış ve gerçekliğin yalnızca süreksiz farklılaşmalarına odaklanmamızı sağlamıştır. Bugün gerçekliği yalnızca, niceliksel fark üzerinden uzamsal kategorilere indirgenmiş bir boyutuyla anlıyor ve üzerinde bunlar sayesinde işlem yapabiliyoruz. Zaten, gerçeklik de üzerinde işlem yapılabilir ve kolaylıkla deşifre edilebilir hazır bir nesneye dönüşmüş durumdadır.

$\mathrm{Bu}$ analiz etme yetisi üzerine kurulu bilgi ve görüntüleme teknolojileri bugün, fiziksel işlemlerin analizini hep daha ileriye taşımakla iki türlü çıkmaza getirip bıraktı bizi: Birincisi, dilin, kendi kendini temsil eden ve bu temsillemeyi sonsuzca götürebilecek olan bir heterotopya olduğunu anladık (Foucault, 2014). Bu bağlamda, yazı teknolojisi ve bu teknoloji üzerine kurulu tüm kodlama sistemleri, ancak kendi kendini temsil edebilen ya da aynalayan ve yaşamın sürekliliğini yakalamakta sınırlı kalan heterotopyalardır. Yazının emperyalizmi ve söz merkezciliğin kaçınılmaz sonucu olarak, dünyanın okunacak bir metin olarak görülmesi (Derrida, 1997) kaçınılmaz olmuştur. Diğer taraftan, analizlerimizde ileriye gittikçe, sonunda gördüğümüz şey, evreni oluşturan heterojen öğelerin sayısının da bir o kadar arttığıdır. Gerçeklik son tahlilde, ne kadar bölersek bölelim, bölünmeye devam ediyor. Sürekli bölünmeye devam ettiğini söylemeyi yetkin olmak elbette gerçeklik hakkında bir şey söyler. Ancak, gerçekliğin yaşamsal hareketini bu bölünme hareketine indirgemek, aralıklarda olup biten oluşun sürekliliğini kavramamızı engelleyecektir. Sonuç olarak, yazı teknolojisiyle güçlendirilmiş dil, yaşamın sürekliliğindeki imajını yakalamakta sınırlı kalmaktadır. Bu 
bağlamda, yaşamın süreksizliğinin ardında yatan sürekliliğini yakalamak için, düşüncenin yeni bir zaman/hafıza teknolojisini devreye sokması gerekir.

\section{Düşüncenin İfadesinde Devrim: Video}

Platon'un felsefi düşünceyi yazıyla ve ide-nesne ayrımıyla tanıştırmasıyla başlayan bu süreç, idealizm ve realizm arasında gidip gelen bir tartışmayı besleyerek bugüne erişmiştir. Felsefe tarihi algılamın kavram tarafından yerinden edilişinin hikayesi olarak da okunabilir (Bergson, 2005). Kavramların algının içeriğinden daha fazlasını içereceğine inandırıldık. Yazı teknolojisi de kurduğu söz merkezli dille, düşüncenin yalnızca kavramlarla yapılacak ciddi bir iş olduğu inancını sabitlemiş oldu. Tarih boyunca başımıza bela olmuş zihin-beden ayrımıyla ilişkili olan algısal yetilerimize güvensizlik, soyutlama ve genelleme işlevlerinin, bedensel kaynaklarından kopuk yalnızca kafatası içi bir zihinsel işlem olarak anlama yetisinde ortaya çıktığına inanmamızdan gelir. Platon öncesi doğa filozofları algılam içinden dünyayı anlamaya daha çok yakındılar. Bu nedenle belki de binlerce yıl önce atom gibi bir fikri ortaya atabilecek ya da temel elementler gibi duyulur olanın içinden bakan bir kavrayışa sahip oldular. Ancak, yazı teknolojisinin de etkisiyle felsefenin büyük projesi, duyulur olanın, saf idelerin gerçekliği açıklama kudreti karşısında tedavülden kalkmasıyla tamamlanmıştır. Duyulurüstü dünya, duyumsanan karşısında bir zafer kazanır.

Kant'ın Kopernik devrimiyle düşüncenin koşullarını sorgulaması ve dünyanın algıda verili olmadığını, bu algının üretilmesinde bir katkımız olduğunu anlamamız üzerinden iki yüz yıl geçti. İki yüz yıl içinde, öznenin bilgi üretim sürecinde merkeze oturduğu bir dönüşüm yaşadık ve zihnin uzantıları olan bilgi ve hafıza teknolojileri öznenin konumunu ve yetilerinin kapsamını gün geçtikçe daha da genişletti. Ancak, bu dönüşümün bedelinin nesneyle ya da daha doğru bir deyişle maddesel oluşla olan bağımızın kopma noktasına gelmesi olduğu söylenebilir. Dünya bedeniyle gittikçe gevşeyen bağımız, bizi varlığın ve oluşun bedenini sürekliliği içinde anlamaktan ve ifade etmekten alı koyan sembolik bir dilsel düzleme hapsolmuş ve dile dönüştürülemez olanı dışarıda bırakan söz merkezci bir değiş-tokuş sistemiyle zapt edilmiştir. Dünyayla birlikte insan ve felsefe büyük bir yaşamsal krizin içindedir. Yarattığımız temsiller dünyasının hipergerçekliği içinde kapalı kaldık. Dil, düşünceyi özgürleştirdiği kadar aynı zamanda etrafına ördüğü duvarlarla, temsile gelemeyen anlamın kaynaklarını önemsizleştirdi ve görünmez kıldı. Yalnızca dile dökülebilir ve deşifre edilebilir olanın ördüğü bu söz merkezci kültürün duvarlarını aşmak ve kaldırımlar altındaki kumsala ulaşmak zorundayız. Felsefede ikinci bir Kopernik devrimini ilan etmek zorundayız. Teknolojinin beden üzerindeki etkilerini ya da daha doğru bir ifadeyle zihinsel sentezlerimizin, dışa doğru genişleten hafıza teknolojilerinin etkisiyle nasıl bir dönüşüme uğradığını anlamak için, yarattığımız teknolojilerin düşüncemizin formasyonu üzerinde ne türden bir dönüşüm sağladığına dönüp bakmak zorundayız. Yani, düşüncenin maddi koşullarını düşünceye dahil ederek düşünmek zorundayız.

Bergson'un zaman ve alg1 felsefesi, saf idelere inanç beslemeye devam ederek algımızın üzerine çıkmak ve onu değilleyerek aşmak yerine, algımızın içine dalarak, algının derinliğini ve kapsamını genişletmeyi önerir. Bu manevra, kavramların gerçekliği sabitleyici hareketinin yaşamın niteliksel farklanmasını, oluşu törpüleyerek anlayan sınırlayıcılığı karşısında algının oluşun zamansallığını dışarıda bırakmayan birleştirici gücünü kullanmaya çağrıdır. Kavramlar, ayırıcı, seçici, birleştirip düzenleyici bir hareket kazandırırlar zekaya. Ancak, zekanın semiyotik işlemlerinin ötesinde, kendisi semiyotik olmayan maddesel oluş, zaman- 
madde ya da Bergson'un en geniş deyimiyle sürenin farklı derecelerden kristalleşmeleri olan bir imajlar bütünü olarak dünya maddesi kendisini ancak algıda açığa çıkaracak bir doğaya sahiptir. Algının içine daldığımızda, yaşamsal oluşun hareketinin içine doğrudan dalarız, kavramların sınırlı çerçevelerinin içinden değil. İmajlarla düşünmek, kelimelerle düşünmekten daha zengin ve derin bir içerik, düşünceyi duyumsamaya yakınlaştırma daha yaratıcı bir sentezleme yetisi sağlayacaktır. Platon'u ters çevirerek söylersek, kavramlar imajların imajlarıdır, biz doğrudan imajlarla felsefe yapmalıyız. Algılam ve imajların, kavramlardan daha fazla içerik barındırdıkları söylenebilir. Saf ideler, saflaştıkları oranda, algıdan niteliksel fark1 ve varlığın zamansal boyutunu dışlarlar. Zeka, onu sürekli bir bölmeye uğrattı̆̆ı için, oluşu kavramda gizler (Bergson, 2005). Zamanı, kronometrik zamana indirgeyerek, yalnızca uzamsal bir semiyotik üzerinden deneyimlenmesine ve anlaşılmasına neden olur. İdelerin değişimi anlayabilmesi, hareket etmekte olan bir trenden aşağı atlamak gibidir. O tren, bir daha asla geri gelmeyebilir. Kavramlar, oluşu süreksizliklerin ardışıklığı olarak kavramak ve buna göre de düzenleyip birleştirmek zorundadır. Yazı teknolojisi, bu özelliği düşüncenin formu haline getirerek, düşünceyi oluşun akışkanlığından ve duyumsanır olandan arındırmaya hizmet etmiştir. O zaman, tez elden algının içine dalarak, zekanın yapabileceklerinin ötesinde, maddenin oluşunun bağrına gömülmüş olan zamanın bölünemez doğasına erişmek için araçlar icat etmek gerekir. Video, bu araçların atasıdır. Bedenin daha uzağı, daha yakını, daha derini, zamanın ve değişimin ritmiyle soluk alıp vererek duyumsamasının yolunu bulması, video gibi doğrudan ışığın kendisiyle düşünmeyi mümkün kılan bir teknolojinin doğuşunu bekledi. Video bedenin, bir protezden fazlası olan uzantısıdır. Öyleyse, felsefeyi kafatası içi bir işleme sınırlandırarak yapmakta ısrar etmek, bizi yalnızca dogmatik bir tutuculuğun istenmeyen çocuklarını doğurmaya mahkum edecektir.

Felsefenin, zaman ve imaj, alg1 ve düşünce ve en nihayetinde zihin ve beden arasındaki sürekliliği yeniden keşfetmesi gerekmektedir. Felsefenin algının içine yerleşmesini sağlayacak olan video gibi kuvvetli araçları keşfetmesi ve geleceğin duyumsanabilir diline kendini yerleştirmesi için manevra yapması gerekir. Algılanabilir olanın bilimine ve sanata bir yakınlaşma hareketi içine girmelidir. Felsefeciler, antropoloji, sibernetik, sinirbilim, bilişsel bilimler, evrimsel biyoloji, yeni medya teknolojileri vb. alanlara kendilerini açarak, bütün bu alanların, yaşamın evriminin ritmini yakalama gibi zor bir görevde ortaklaştıklarını görmelidir. Ancak, her birinin başka bir ortak noktası daha var, hepsi insanın uzantıları olan teknolojinin dilleriyle iş yapmaktadır. Yazı teknolojisinin el verdiği yazılımlar ve kodlama sistemleri, tüm bu alanların ortak dilini oluşturmaktadır. Bu dilin, düşünceyi uzamsallaştıran ve zamanı mekânsal kategorilere indirgeyen bir dilin ürünü olduğu söylenebilir (Bergson, 2005). Zamanımızın kodlama sistemleri, zamanı, isimler, noktalar, çizgiler, göstergeler ve kavramlarla sentezlemektedir. Temsil sistemleri olarak görülebilecek bu düzenekler, çok uzun zamandır alg1 ve gerçek, kod ve alg1 arasına set koymamıza neden oldular. Bu set opak maddesellik oldu. Gerçekliği yalnızca maddenin edimselliğiyle açıklama eğilimi gösteren anlam rejimleri geliştirdik. Ancak aynı zamanda, aynı kodlama sistemleri sayesinde zamanı daha doğrudan bir yolla sentezleyecek ve insan algısının doğallığının erişemediği saf algıyı oluşturabilecek bir teknolojinin doğuşuna tanıklık ediyoruz. Görüntüleme sistemlerinde gerçekleşen bu yeniliğin sonucu olarak video, algıyı temsillere indirgeyen dilin sinırlarını bize gösterecek olan bir değişimin habercisidir. Bizi temsiller yerine algının doğrudan içine yerleştirerek gerçeklikle sürekliliği içinde ilişkilenmemizi sağlayacak olan, zamanın içindeki farklanmaları mekânsal olana indirgemeden zamana daha doğrudan bir kapı açmaya yarıyor. 
Video bizi, bedeni yeniden keşfetmeye ve bedenin içinden onun kuvvetleriyle düşünmeye götürecek ve bilincin yüzeydeki semiyotiğinin ötesine, maddenin oluşuna ve bilinçdışının dilsel olmayan alanına taşıyacak olan imajlardan köprüyü kurar. Ulus Baker'in (2015) işaret ettiği gibi, video sanatının ilk kaşiflerinin, kamerayı bedenlerine tutmayı akıl eden kadın sanatçılar olması bir tesadüf olamaz. Bedenden kopuk zihnin tekno-emperyalizminin yarattığ1 sözmerkezci hakimiyetin artık sonu gelmiştir. Yeni çă̆, zihinlerin bedenlere geri döndüğü, bizi hayali bedenler yaratarak köleleştiren kapitalist kapma aygıtlarına karşı bir dil inşa etmeyi başarabilmiş, bilgi üretimine bizzat dahil olduğunun farkında bedenlerin çağıdır. Yazı teknolojisinin fikirlerin mülkiyetine dayalı despotik çözümleyici ifade formu, erkek egemen bilgi iktidarının son demlerini yaşıyor. Bilginin olaydan ve bedenlerden kopuşunu garanti altında alan ifade formları içinde kalmaya devam ettiğimiz sürece, düşüncenin cinsiyetlendirilmiş formlarını yeniden üretmekten kurtulamayacağız. Yazı, aklı duygulardan ayıran, duyulurüstüne ulaşma çağrısında insanlığı birleştirerek ona yön verme derdindeki erkek bir tanrının sözünü aktardığı dildir. Antonin Artaud'nun (2002), otopsi masasına yatırarak insanın içinden çekip çıkarmak istediği organ, içimizdeki Tanrı organı bilinçtir. Bilincin dili olan yazıyla felsefe yaptığımız iki bin yıllık bir çă̆ kapanıyor. Düşüncenin güzergahını, bedenden başlayıp, başta zihin-beden, duygu-akıl, ide-algılam, alg1eylem ikiliklerini tek tek eleyerek, Nietzsche' nin üstün bedenine ulaştıracağız. Düşünceyi, düşüncenin düşüncesi olmaktan çıkararak yalnızca sözcükler ve gramatik oyunlar içinde düşünüleceğini bize dayatan despotik sözmerkezciliğe karşı, duyularımızın uzantıları olan hafıza teknolojileri ile maddenin içine yerleşerek, düşüncenin bedenlenmesinin yollarını inşa edeceğiz. Böylece, bedenli olmanın tenin sınırlarında bitimli olmadığını, algının bize birden fazla da bakış açısı sunabildiğini göstereceğiz. Yazının ulaşabildiği en yüksek bakış açısı, aşkın, soluk, sayıca epey az denebilecek sadece tek bir Tanrı imgesinde belirebilmiştir. Oysa, algılamın derinliklerine dalmak bize varlığın içkin farkını, varlığın oluşuna ait eşsiz yaşamsal kuvvetlerinin çoklu ifadesini gösterme kudretine sahiptir. Videonun tanrısı doğa, bildiğimiz bütün tanrılardan daha zengin ve daha yüksek bir çözünürlüğe sahiptir. Bilince ulaşana kadar düşünce çoktan yönünü ve değerini bedenli bir yoldan ilerleyerek kazanmış oluyor. Bilince ulaştığında, bölünerek ve sınıflandırılarak bir sabit gösterge halini alıyor. Video gibi bir teknoloji, insan bedeninin yararlılık ve değer biçme süreçlerine uğramadan, yani düşünce bir organizmanın örgütlenişinin hiyerarşisine tabi tutulmadan ne rasyonel ne de söylemsel olan organik-öncesi fikirlere bizi açar. Ses, doku ve hislerle düşünme; kelimelerin ötesindeki imgelerle düşünme. Düşünme bedensel kaynaklarına geri çağrıldığında, kendisi düşüncenin önünde bir engel olmaktan çıkar ve düşünülmeyenin içine kulaç atarız. Bergson’un deyimiyle, imajda kavramdan daha fazla gerçeklik vardır. Sonsuzca birbirine bağlanan imajlar arasında, insan bedeninin sınırlarını aşan ve onun ötesine uzanan imaj tarlalarında gezinebilme olanağının, aklın emperyalizminden kurtulmuş bir üstün bedenin doğuşuna işaret ettiği söylenebilir.

\section{Video neyi vaat ediyor?}

Video Zamanın Doğrudan Sentezidir Yazı teknolojisi bu anlamda, bedenin zihinsel sentez yapabilme kapasitesinin evriminde geçmesi gereken bir ara evre olarak düşünülebilir. Sinema ise, zihnin erginlenme ritüellerinin en renklilerini sunmuştur. Bilinçdışının büyük keşfine giden yollar, zamanın kristalleşmelerinin en yaratıcı formları aracılığıyla sinema endüstrisinin bantlarında üretildi. Sinema, yazıya bir ses kazandırdı ve onun kendi adına konuşmasına izin verdi. Ancak, video teknolojisi, sözlü kültürün ikinci ama bu defa bambaşka araçlarla 
yeniden doğuşunun habercisidir. Video yanıt vermeyi gerektiren bir teknoloji sunar. Karşılıklı etkileşim, imajla bakan arasındaki mesafeyi kaldırır. Bu mesafe üzerinde, komutla, şimdilik klavyeyle video üzerinde eyleyebilirsiniz. Bu anlamda imaja dokunabilirsiniz. İmaja doğrudan erişebilirsiniz. Dokunmatik ekran imajın bir uzantısıdır. Ekran üzerinde eylemek imaj üzerinde eylemektir. Bu durum, videonun aracılık ettiği bir felsefeyle, felsefenin yeniden bir diyaloğa dönüşme ihtimalini doğurur. Böylece felsefe, köklerini Platon'un temsiliyetçi bakışından çok, Sokrates'in hayatın içindeki yaşayan felsefesinin içinde hem bir olay hem de bir diyalog olarak bulacaktır. Video, düşünceyi, sinemanın dilsel kurallara dayalı anlatı rejimlerinin ötesinde kurmaya yarar. Sinema makinesi bizi zamanın yakalanabileceği fikriyle tanıştırmıştır. Sinema ve film, yazı teknolojisinin ürünü olan anlatılandırma işlevinin son kalıntılarıdır. Sinema, düşünceye yeniden sesi dahil ederek ve zaman-imajı yalnızca estetik süreçler aracılığıyla da olsa keşfederek, video teknolojisinin doğuşunun habercisi olmuştur. Fakat, göstergeler ve bunların okuryazarlığını yaratma ve sürdürme pratiği üzerine kurulu olmaya devam ettiği sürece zamanla yakaladığı daha doğrudan bağı hep kaybedecektir. Video bu anlamda, dilsel yapılar ve gösterge sistemleri yaratma mantığı üzerine kurulu temsil sistemlerini geride bırakacak bir yeniliktir. Gerçekliği simule etme gereği duymadan, zamanın üzerinde doğrudan işlem yapabilmemizi sağlar. Videoyu anlamak için bir temsil teorisine ihtiyacımız yoktur. Bundan sonra nesneyle ilişkiye geçmek için onu mekana yerleştirmeye, ya da imaj1 açıklamak için zihne başvurmaya gerek yoktur. Gerçeklik ve kavram arasına koyduğumuz boşluğa benzer şekilde, gerçeklik ve imajı arasına bir boşluk koyarak bu imaj "aracılığıyla" düşünmeye ihtiyacımız yoktur. Çünkü, zamanın kristalleşmesi olarak video bize gerçekliğin doğrudan kendisiyle düşünme imkânı sunmaktadır. Fenomen ve numen arasında bir ayrım yapmayı bir kenara bırakmamız gerektiğini öğütleyen bu türden bir ontolojiyi anlamak için Bergson'a kulak vereceğiz. Varlığın, oluşun ve her şeyin oluşmasını sağlayan zamanın, bir diğer deyişle enerjinin, farklı derecelerden sıkışıp gevşeme hareketinin ürünü olarak, kronometrik zamana indirgenemeyecek içkin niteliksel fark olduğunu kabul ettiğimiz yerde, icat ettiğimiz zamanı kristalleştirme makinelerinin zamanın içinde ve bizzat onunla çalıştığını dünyayı temsil etmediğini kabul etmeliyiz. Video bedene bir eklenti ya da bir protez olmaktan çok, zamanda hareket eden bir bedenin bir kuvvet derecesi ya da eyleme kapasitesi olarak onun uzantısı olma işleviyle ortaya çıkmıştır. Video, algı, duyum ve hafıza gibi zamanın sıkışma ve gevşeme hareketinin ürünü olarak onun kristalleşmesi olarak görülebilir. Bu da onu, imajın ve gerçekliğin birbirinden ayrılmasını gerektiren temsiliyetçi anlayıştan kurtarır. Çünkü, video ışığın analog ortamda kimyasal bir izi değil, doğrudan ışıktan ibaret bir ontolojiye sahiptir.

Video sayesinde imajın ötesine geçerek, saf algı boyutuna ait olan bir şeye, 1şık akışlarına, madde-akışlarına erişiriz. Bilincimizin erişemediği yere bizi eriştirir. Bütün olanaklı algıların toplamı olan kaostan, videonun elektromanyetik filtreleri sayesinde kurallı algılara ulaşırız. Fakat bu kurallı algı, saf algıya bizim duyularımızın filtresinden daha yakın bir filtre sunar. Videonun bize açtığı saf algı bizi alışık olduğumuz homojen mekan ve zaman kategorilerini bırakmaya zorlar. Zaman ve mekan bizim eyleme gücümüzün şemalarıdır, bu şemaları bıraktı̆̆ımızda, algı-maddeye açılırız. Kuvvetlerin dünyasına doğal algımızın sınırlarından kurtularak açılırız, nitelik ve niceliğin, uzamsal olan ve olmayanın bir karışımıdır bu. Mekanın ötesine geçerek zamanla bir ilişki kurma olasılığı doğurur video. Böylece yaşamın sürekliliğini bildiğimiz göstergelerin ötesinde yeniden oluşturabilme şansı yakalarız. Vertov'un çok önce kameranın gücünü keşfettiğinde söylediği gibi, gözlerimizi olduklarından daha iyi bir konuma getiremeyiz ama kamerayı sonsuzca yetkinleştirebiliriz (Vertov, 2007). Bu nedenle, videonun doğal algımızdan daha gerçek olduğunu söyleyebiliriz. 
Video teknolojisi felsefeciler için, biri ontolojik diğeri ise epistemolojik iki temel tespiti beraberinde getirir: birincisi, video, zamanın doğrudan kendisine açlan bir ontolojiyle bizi tanıştırır. Zihin nasıl zamanı kristalleştiriyor, yani yaşantıyı anılara dönüştürüyorsa, video da, zamanın doğrudan sentezini yapabilme kapasitesine sahip bir "zamanı kristalleştirme" teknolojisidir (Lazzarato, 2016). Video kameranın özgürleştirici etkisi, doğal algımızın dayandığı ihtiyaçlar üzerinde yükselen filtreleme/çerçeveleme mekanizmaları olmadan bizi saf algıya bağlamasında yatar. Video, Bergson'un zaman konusundaki görüşlerinin sağlaması ve doğrudan kanıtı gibidir; beynin kendisi de dahil olmak üzere bizzat gördügüumüz dünya, imajlardan ibarettir ve bu imajlar bize gerçekliğin kendisini verir. Arkalarında temsil ettikleri bir asıl gerçeklik yoktur. Bergson felsefesi bize bu imajların, enerjinin yani aslında zamanın kendisinin farklı derecelerden sıkışma ve gevşeme hareketinin bir ürünü olduğunu ve enerjinin zamana eşitlenerek anlaşılabileceğini öğretir. (Bergson, 1913) Zaman, Einstein'ın iddia ettiği gibi varlığın dördüncü boyutu değil, varlığın kendisidir Bergson’a göre. Bergson'un sunduğu şu eşitlik bizi teknolojiyi ve duyulur olanı fenomen-numen ayrımına düşmeden kavramamızı sağlayacak bir ontoloji sunar: imaj $=$ hareket $=1 s ̧ 1 \mathrm{k}=$ madde $=$ zaman. $\mathrm{Bu}$ nedenle video, enerjinin yani zamanın doğrudan sentezlenmesi olarak görülebilir (Lazzarato, 2016: 55). Video (sesler ve imajlar), zaman-madde yani elektromanyetik dalgaların doğrudan işlenmesi olduğu için bizi zamanın algısına daha doğrudan bir yolla ulaştırır. Bizi ne gösterge olan ne de gösteren, 1şı̆̆ın saf titreşimlerini kapmaya açar. Göstermeyen akışlarla gösteren akışlar arasında ilişki kuran makinesel bir düzenlemedir (Lazzarato, 2016: 54). Nesnelerdeki hareketlerin, frekansların, atomların ve enerjinin algısını mümkün kılar. Bu bağlamda bizi, Bergson'un "saf alg1" dediği durumun içine yerleştirir (Bergson, 2007: 100). Saf alg1, zihinsel sentez tarafından sahiplenilmeden yani deneyimin ötesindeki maddenin, imajların ve hareketin özdeş olduğu düzlemdir (Bergson, 2007: 105). Algıladığımız dünyanın arkasında kendinde bir gerçeklik yatmaz, bedenimiz ve beynimiz de dahil dünya bir imajlar akışından ibarettir. Bu imajlar birbiriyle çarpışır, birleşir, çözer, çözünür, etkiler ve etkinir. Bu karşılaşmalar, kuvvetler, yeğinlikler, oluşlar meydana getirir. Bergson işte bu imajların saf hareketini enerjiyle eşitler. Böyle bakıldığında evren, sonsuz varyasyonda titreşen bir ışık akışı olarak görülebilir. Saf alg1 var olmak ve anlamını bulmak için bilince ihtiyaç duymayan, yani var olmak için algılanmaya ihtiyaç duymayan kendinde imaj akışıdır. Bu anlamda, şeylerin kendi algıları vardır. Saf algıda imajların etki ve tepkileri iç içe geçmiştir. Her imaj alımlayan ve ileten bir eylem merkezidir. İmaj, enerjinin ya da diğer deyimiyle zamanın saf titreşimidir. Biz saf algının kendisini değil ancak onun farklı derecelerden sıkışmış hallerini algılarız. Fakat, video gibi doğrudan ışığı sentezlememizi sağlayacak bir teknoloji, bize saf algının imajlarına ulaşma ve onlar üzerinde işlem yapabilme yetisi sunar.

Yazı teknolojisinden türetilmiş kodlama sistemlerinin bizi ulaştırdıkları son teknolojik gelişim noktasında, ışı̆̆ın doğrudan kendisiyle bağlantı kurmamızı mümkün kılarak, bu kodlama sistemlerinin izin verdiği temsil gücünün çok ötesinde bir yeti kazandırmıştır beyne: zamanın kendisini yakalamak ve üzerinde işlem yapabilmek. Video ve bedenin çalışma prensipleri arasında bir paralellik olduğunu gösterebiliriz; video nasıl zamanı sentezleyerek/sıkıştırarak algıya dönüştürüyorsa beden de bundan farklı çalışmaz. Videonun çalışma prensiplerini anlamak insan algısının ve hafızasının nasıl çalıştığı hakkında bizi bilgilendirebilir. Video da beden de gerçekliğin imajlarda sentezlenmesidir. Yazı teknolojisi, bedenin kapasitelerini genişlettiği ölçüde, temsillerin gerçekliğin yerine koyulması nedeniyle onu aynı zamanda köreltmiştir de. Duyumsamanın yollarını daraltmış, duyular arasında hiyerarşiler ve duvarlar kurulmasına neden olmuştur. Zihinsel sentezlemelerimizi maddi 
sentezler olarak göstergelere indirgemiştir. Düşünceyi yalnızlaştırmış, düşünce kendi içine kıvrılmıştır. Düşünceyi eylemden koparmıştır. Onu, zamanla olan duyumsal ve duygulanımsal bağından koparmıştır. Oysa video, zamanı ölçülebilir ve bölünebilir birimlere indirgemeden zamanla kurduğu doğrudan bağ sayesinde bize temsil sistemlerinin ara yüzü olmadan varlıkla doğrudan bağ kurma şansı kazandırmıştır. Bugün bilimlerce, algı ve düşüncenin oluşum koşulları açısından daha doğru bir imgesi oluşturulabildiyse, bu, MRI ve EEG gibi beyin görüntüleme sistemlerinin zamanı daha doğrudan yakalayabilmesi sayesinde mümkün olmuştur. Beynin aktivitesini görselleştirmek beyne kendi hakkında daha doğrudan bir bilgi sağlamıştır. Bedenimiz bir uzantısı olarak yarattığı dilin engellerini aşabildiği için, dil öncesi ve dil üstü zamansal akışlarla daha doğrudan bir bağlantı kurabildik ve varlığın oluşuna dair daha yakın bir bilgiye erişebildik. Bu bağlamda, bilgi tanımlarımızı yeniden gözden geçirmek zorundayız. Bilgi artık bilen ve bilinen arasındaki boşluğun ortadan kalktığı bir düzlemde üretilecektir. Bu etkinin, elektron boyutunda en bariz şekilde gözlemlendiği yerlere bakarsak, gerçekliğin oluşunda gözlemcinin etkisini hesaba katmak gerektiği gerçeğini yine görüntüleme teknolojisi sayesinde gördük. Beyin artık bilgiyi yani dünyanın imajlarını üretmiyor, aksine farklı sentezleme sistemleriyle gerçekliğin imajlarına doğrudan bağlanabiliyor. Bu bağlamda, video yazı teknolojisinin aksine gerçekliğin temsilini üretmez, aksine bizi, gerçekliği duyularımızın ötesinde bir yetiyle algılama kapasitesine eriştiren bir işlev görür.

Video Beynin Uzantısıdır Video işlemeyle beynin diğer bir işlevini sağlarız; istemli hatırlama ya da bellek! Alg1, imaj ya da 1şık akışlarından tekrar eden titreşimlerin yakalanarak süreklilik arz eden duyumlar olarak sıkışmasıyla ortaya çıkar (Bergson, 2007:133). Bellek ise, maddi sentezin ortaya çıkardığı bağımsız anıları kendi aralarında birleştirme, birbirine uymasını sağlama ve böylece süre ya da başka bir deyimle ritim oluşturma kapasitesidir. Özne ya da bilinç imaj üretmez, o imaj akışları içinden seçme işlemini yerine getirir. Bedenler, hareketi alımlamak ve onları eyleme dönüştürmekten başka bir şey yapmazlar. Bir beden, etki ile tepki arasına bir zaman, bir belirsizlik, gücül olasılıklar içinden bir seçim olanağ1 yerleştirir. Bu aralıkta saf algıda olduğu gibi kendiyle özdeş olmayan, yaşadığı bir etkiye daha karmaşık tepkiler verebilme olanağıyla belirir. Benim bedenim de diğer imajlar içinde hareketi alımlayan ve geri gönderen bir imajdır yalnızca, ancak hareketi nasıl geri döndüreceğini kendisi seçer gibi görünür (Bergson, 2007: 49). İşte bu noktada beyin, alımlanan hareket ile iletilen hareket arasında bir ara yüz işlevine sahiptir; bu aralığı azami düzeye çıkarmaya çalışır. Böylece, eylemlerle etkinme arasında seçim şansı doğar. Bir salyangoz da hareketi alıp geri iletir. Ancak, etki ve tepki arasındaki mesafe oldukça kısadır. Onun tepkilerinin refleksif olduğunu söyleriz bu nedenle. Benim bedenimi salyangozunkinden ayıran, seçim yapabilmemi sağlayacak kadar geçmiş deneyimin ya da anının bedenimde birikebiliyor olmasıdır. Bellek, beynin ve sinir sisteminin gelişimiyle etkinme ve etkileme yani eylem arasında bir gecikmenin, bir aralığın oluşabilmesini sağlar. Bu aralığa duygulanımsal bir kuvvet girer. Bir eylemin geciktirilebilmesi, gücül bir hafızanın doğurduğu seçenekler sayesindedir. Beyin ve sinir sistemi karmaşıklaştıkça, yani hafızam genişledikçe eyleme kapasitesi de doğru orantılı biçimde artar (Bergson, 2007: 58). Bergson beyni bir telefon santraline benzetir, eylemi bekletme ve sonra iletmenin düzenlendiği yer olarak (Bergson, 2007: 24-5). Alımlanan hareket açısından analiz işleviyle, uygulanan hareket açısından da bir seçim aygıtı olarak işlev görür. Ancak burada görülmesi gereken asıl önemli nokta, beynin bu hareket imajlarının üreticisi olmadığı gerçeğidir. Beyin ışık akışlarının yani imajların gidişini sürdürür ya da dönüştürür, onların üreticisi değildir. imajlar beynin içinde değildir, beyin imajların içindedir (Bergson, 2007: 1123). Kısaca beyin, imajlar yaratarak dünyadaki nesnelere algı eklemez. Aksine, imaj-maddeden 
kendi için yararlı ve bedenin eylemliliği için değerli olanı çekip çıkarır ve alıkoyar. Kısaca, imaj beynin nesnelere eklediği bir şey değildir, o sadece imaj akışları içinden bazılarını seçer. Beynin yaptığı şey algıyı sürdürmektir. Ancak, bu sürdürme işini yaparken hafızanın alışkanlıkların ötesinden virtüel boyutundan da beslenir. Bu anlamda video kamera, beynin işlevinden farklı bir işleve sahip değildir: "video kamera, zaman-imaja dalmış bir bedendir; saf algının sürekli varyasyon halindeki akışlarını kaparak ve kristalleştirerek kendi aralığını yaratan ve maruz kalınan eylemlere bağlı olarak az ya da çok geciktirilmiş bir eylemi inşa eden bir beden" (Lazzarato, 2016: 36). Video da beden de, imaj akışları içinden seçtiği imajları bekletme ve geri bildirme aralığında duygulanımı inşa eder. İkisinde de, etki ve tepki arasına duygulanımlar yerleşir. Duygulam, etki ve tepki arasındaki geçişin hissedilmesidir, beden kendi kendini hissederek bilgilendirir. Duygulanımların yön verdiği virtüel bir hafızanın içinden yeni olan bir eylemlilik hali doğacaktır. Duyum ve duygulanımsal kuvvet, bedenin uzamlı hareketini yeğinlikli harekete dönüştürmesidir. Zihinsel etkinliğin sırrını çözmeye çalışırken peşinde olduğumuz soru, uzamlı algının uzamsız duygulanıma nasıl dönüştüğüdür. Duygulam, diğer imajların bizim bedenimiz üzerindeki olanaklı eylemliliğin ölçülmesi olarak algının bedensel bir duyuma dönüşmesidir. Duygulam, algının bedenin sınırları dahilinde yoğunlaşmış bir algılama halidir. Duygulam, kendi kendinden etkilenmedir. Bütün canlılar, hareketleri algılar, onları iletir ve ürettiği duyumlarla bu hareketleri soğurur. Bedenler arasındaki fark, onların eyleme kapasitelerindeki derecesel farktır. Bir bedenin eyleme gücü ne kadar büyükse, algıladığı alanın kapsamı da o kadar büyür. İşte video, alg1 alanının kapsamını yatay olarak arttıracaktır. Diğer yandan, zamansal olarak dikey olarak arttırdığı da söylenebilir; çünkü videonun da aralığa giren duygulanımsal kuvveti meydana getirme kapasitesi vardır. Video, sadece duyusal-motor bir kayıt değildir, aynı zamanda zamanı kristalleştirerek virtüel bir bellek olarak da çalışır. Video, zamanı araya sokabilir, onu biriktirebilir, saklar ve şimdiye getirir. Böylece, bir gecikme yaratır. İşte bu gecikme aralığında videonun zaman-imajlarını işleme işlevi devreye sokularak yeni duygulanımsal kuvvetler doğuracak virtüel imaj toplanışları çağrılmış olur.

Video, imajları yarattığımız bir sistem değil işlediğimiz bir sistemdir. Maddi sentezden zihinsel senteze geçiş, video işlemeyle (montaj sinemaya ait bir kavram) mümkün olur. Videoyu sinemadan daha canlı kılan şey: zamana müdahale etme kapasitesidir, oluşmakta olan şimdi üzerinde eylemek için zamanı kullanabilme kapasitesidir. Bu nedenle, video-imaj karşısında ne sinefilin istediği gibi sadece göreniz, ne de TVnin istediği gibi dikizciyiz; akışa bağlanabilir, onu işleyebilir, dönüştürebilir ve yeniden işlenmesi için dönüşüme sokabiliriz (Lazzarato, 2016: 91). Video eylem alanıdır. İmajı işleme gücünün hem devlet hem de iletişim grupları tarafından denetlenmesi ve kodlanmasının ötesine geçmek için harekete geçmek gerekir. Video özneden özneye değil, mekandan mekana durumdan duruma etkileşimi mümkün kılar -canlı yayın (aktaran Lazzarato, 2016:24). İşte, bu etkileşim ve geçmiş bağımsız anılarda varlığını sürdüren bir kayda ulaşabilme imkanı, videonun virtüel imajlar üzerinde işlem yaparak, bu gecikme aralığında düşünmeyi ve eylemi harekete geçirmek için kullanılabilir politik imkan barındırmaktadır. Bellek, virtüel ile edimsel arasında bir arayüz olarak işler: süreyi sürdürmek. Beden, hareketin eylemde sürdürülmesi olarak kaslarda tutulan alışkanlık hafızasını kullanır, bunun videonun gerçekliği doğrudan kaydına tekabül ettiği söylenebilir. Diğer tarafta, tıpkı beynin bir işlevi olarak dikkate dayalı hafızada olduğu gibi, video sadece bir kayıt olmaktan çıkıp işlenebilir ve seçim olanaklarına dönüştürülürse yalnızca edimselleşmiş olan kayda indirgenemeyecek virtüel varyasyonlar meydana getirir. Edimsel ve virtüel, algılanan imajlar ve anıya dönüşen imajlar zihinsel sentezin birbirine bir 
şimdide bağlı iki ucudur. Bedenimiz algılarken, geçmişimizi şimdimizle buluşturmak için sıkıştırır, diğer yandan dikkat gerektiren hatırlama eyleminde ise kendiniz geçmişin farklı düzeylerine yerleştirmek için geçmişi genleştirir. Bu iki yönlü hareket en nihayetinde ortaya duygulanımsal bir kuvvet çıkaracaktır, zamanın sıkışması ve genleşmesi duygulanımla ayrılmaz biçimde iç içedir. Kronometrik olmayan zaman, temsile gelmesi mümkün olmayan duygulamdır. Belleğin bu iki işlevi, her türlü deneyimin otomatik kaydı ve sıkışma-genleşme hareketi sayesinde algının ve imajların mümkün hale gelmesi sürecine tekabül eder. Kısaca, birinci olarak video, "beyin gibi, yani akışların akıp gidişine bir aralığı, bir dönüşümü dahil eden bir akım çevirici gibi işlev görür... Göstermeyen bir akışı gösteren akışa dönüştürerek zaman-maddeyi sıkıştırır ve genleştirirler. Saf titreşimleri, sarsıntıları, maddenin titremelerini (gevşeme ve sıkışma yoluyla) imaj biçiminde kristalleştirirler" (Lazzarato, 2016: 54). Tüm bu süreç sırasında, insan bedeninin fizyolojisinin sınırlarına takılmadan hareket edebilirler. İkinci olarak da, zamanın farklı düzeylerinde dolaşarak zihinsel sentez ortaya koyma kapasitesine sahiptir. Sıkışma ve gevşeme hareketi, geçmişin imajlarına dönebilir ve video teknolojisi imaj işleme teknikleri sayesinde belleğin işlevini yerine getirerek imaj üretimine girişebilir. Video işleme, imajların dış yüzeyleri arasında bir bağlantı kurmak değil, onların ortaya koydukları duygulanımsal kuvvet dereceleri arasındaki bağlantıları kurmaktır. Kısaca, video-bellek aracılığıyla imajların işlenmesi, kuvvetler arası zamansal ilişkileri bulup çıkarmaya hizmet eder, görme gibi sadece algısal öğelere indirgenmiş şematik bağlantıların yapbozunu çözmeye değil. Video kamera, sıkıştırma ve gevşeme hareketiyle elektromanyetik dalga akışlarını modüle eder ve böylece zaman-maddenin kristalleşmesini sağlar. İmaj işleme teknolojileri sayesinde ise, virtüel belleğin içinden zihinsel emeği taklit ederek yeni potansiyel bileşimler çıkarmayı başarır. İşte bu zihinsel emek, videonun insan bedeninde taklit ettiği yegâne şeydir. Kaydedilen hareketle, onu iletmeden önce bekletip düzenleme/işleme sürecindeki bu belirsizlik ve aralıkta, politik duygulanımlar sığdırabilecek ve yeni eylemlilikler doğurabilecek devrimci eleştirel bir potansiyel yatar. Video, zamanın kendini yeniden bir kuvvet olarak tesis etmesinin yoludur. Kısaca video, aktif bir sentez süreci olarak algı ve belleği taklit ederek insanın bilişsel kapasitelerinin bedensel sentezlerinin ötesine geçmesini sağlar ve kendi virtüel nesnelerini üreterek düşüncenin sınırlarını genişletir. Algımızı ve belleğimizi doğallıktan çıkararak, eyleme gücümüzün kapsamını arttırır. Video teknolojisinin sıkıştırdığı ve genleştirdiği madde, zaman-madde ve belleğin farklı zamansal katmanlaşmalarıdır. Video, zamanın farklı sentezlerini taklit eder ve bu taklit sayesinde duygulanımsal kuvvet üretiminin koşullarını hazırlar. Video işlerken, ışı̆̆ı yani zamanı işlersiniz. Bergsoncu zaman-maddenin kendisiyle düşünmektir video. Kavramlar ve yazı teknolojisiyle desteklenmiş dil, oluşu sabitleyen teknolojilerdir. Bizi yanılsamalar dünyasına kapatır. Oluşu sabitlemenin fetişizmidir (Lazzarato, 2016: 60). Dil, bilinci, maddi nesnelere sabitlenip kalmasından kurtarmıştır, ancak bir taraftan da yarattığ gerçekliğin yerine geçen simülasyonuyla bizi imajların kendisinden uzaklaştırır. İmajların kendisi kavramlardan daha fazla sürekliliği yakalayabilir, çünkü onlar bizzat zaman-maddenin kendisinden meydana gelmiştir. İmajlar, kavramlardan daha fazla değişimin ritmini yakalayabilir ve onun içine nüfuz edebilirler.

Video, bu bağlamda, beynin ürettiği teknolojilerle doğal algısını aşmaya çalıştığının göstergesidir. Hali hazırda, videonun etkileşimli ve gerçek zamanlı formları geliştirilmiştir. $\mathrm{Bu}$ bilimin ve sanatın sezgileri sayesinde gerçekleşmiştir. Bilginin ve düşüncenin telifi yazı teknolojisinin bir kalıntısıdır. Telif ortadan kalkacak ya da en fazla kapitalizmin bir sorunu olacaktır. Videonun şu anda sağladığı kolaylık kayıt yapabilmedir, ama bir süre sonra kayıt altına almanın da bir anlamı kalmayacaktır. Bütün kategorilerimizin zamansal kategoriler 
haline gelmesinin düşüncede büyük bir sıçrama yaratacağı neredeyse kesindir ve bu durum bedenin nasıl bir sentezleme sistemi olduğunu keşfetmemizle mümkündür öncelikli olarak. Felsefeciler olarak, zihin ve video arasındaki benzerlik üzerine daha fazla eğilmemiz ve yazı teknolojisinin imkanlarını aşan teknolojilere yeni düşünce yolları olarak başvurmaya kendimizi açmamız gerekir. Felsefecilerin, bizi gelecekte video ve beynin tam entegrasyonunun beklediğini görmeleri gerekir. Bu anlamda, geleceğin diliyle felsefe yapabilmek için video işlemeyi pedagojik formasyonumuz içine almak zorundayız. Video ve yazılım, geleceğin anlam üretme ve bilgi aktarım dillerini oluşturuyor. Video teknolojisi, felsefecilerin duyumsallığ ve onun teknolojiyle ilişkisini yeniden düşünmeleri için doğru bir adres sunar. McLuhan'ın uyarısına kulak vermek gerekir: "medium is the message" (McLuhan, 1994). Geleceğin düşünce dilinin duyusal ve duyuşsal malzeme olacağını ön görebilirsek, düşüncemizin de bu malzeme tarafından şekilleneceğini kabul etmek zorundayız. Bilgisayardan çok bir video makinesi gibi işleyen zihin, icat ettiği araçları düşünme sürecinin bir parçası haline getirdiğinde, bedenin yaptığı işi devam ettirir. Bu araçların yaptığı iş, bedenin dinamik sistemlerinin parçası olan nöral ağların yaptığı şeyden farklı değildir. Bu bağlamda, videoyla bilişsel bir entegrasyon deneyimlemeye onu icat ettiğimiz andan itibaren başlamış olduğumuz söylenebilir. Algımızı besleyen ve onun ötesinde bir gerçeklik deneyimi kurmamızı sağlayan hafıza, zihinsel etkinliğimizin gücül boyutunu oluşturur ve bir dijital teknoloji aygıtı olarak video bu gücüllüğün kuvvetini arttırma kapasitesine sahiptir. Video bu anlamda, tıpkı yazı gibi bir "hafıza teknolojisidir" (Lazzarato, 2016). Video, beynin dış dünyadaki bir uzantısıdır. Bedenin bir uzantısı olarak video, bedenin sınırları ötesinde onun etkime ve etkinme uzvu olarak işlev görmektedir. Genişletilmiş zihin kuramına göre, bedenin dışındaki nesneler de zihnin bir parçası olarak işlev görebilirler (Clark ve Chalmers, 1998). zihni sadece kafatası bir işletim sistemi olarak görmek oldukça sınırlayıcıdır. Bu bilişselci yanlış anlamanın temelinde, zihnin, bedenin ve çevrenin birbirinden keskin sınırlarla ayrılabileceğine inanmak yatar. Bedeni, hareketsiz, pasif ve değişim için ancak kontrol sağlayacak bir bilince ihtiyaç duyan atıl bir cisim olarak görmenin sonucudur. Bedeni zamansallığıly birlikte bir eylem ve hareket merkezi olarak gördügünüzde, onun tüm etki ve etkinme dinamiğinin çevreyle girdiği eşleşmenin sonucu olduğunu görebilirsiniz. Bedenin ve zihnin eşleştiği her sistem bilişsel sistemin bir uzantısı olarak görülmelidir, protezi olarak değil. Video kamera ve aynı zamanda imaj işleme teknik ve teknolojileri öncelikle algı ve sonra da hafıza işlevlerini yerine getiren bedenin bilişsel uzantıları olarak görülebilir.

Videodïşünürlere Notlar Video gibi bir teknolojik uzantının bedenimize kattığı gücü tanımayı reddettiğimiz sürece, onun zihnimiz ve yaşantımız üzerindeki yan etkilerini de bertaraf edemeyiz. Video, kapitalizmin öznellik üretiminde bir "kapma aygıtı" (Deleuze ve Guattari, 1987) olarak çalışır ve simülasyon teknolojileriyle sayesinde temsil makinesine dönüşen bir boyutuyla düşünüldüğünde, beraberinde gerçeklikten kaçış kültürü getirir (Lazzarato, 2016). “Gösteri toplumunun” birincil aracı olduğu çok doğrudur. Ancak, gösterinin aracı olduğu tespitinde bulunmak yeterli değildir. Eğer bu durumu sadece eleştirmek değil, aynı zamanda değiştirmek istiyorsak, yapmamı gereken makinenin ya da programın içine girmek ve nasıl çalıştığını öğrenmektir. Gösteriye direnmek ancak onun koşullarını bilerek, ona karşı bizzat kendisiyle direnerek mümkündür. İmajın ve temsilin bizi ne kadar yabancılaştırdığını söylemek ancak sistemin nasıl çalıştığını bilmemek ve o dille konuşamamak bir eksiklik olarak görülebilir. Dili eleştirip, o dilde yazamamak gibidir. Yazmayı iyi çözemeden, yazıyı eleştiremeyiz. Bu nedenle felsefeciler olarak, geleceğin duyumsanabilir dilini üreten teknolojilerin dilini çözmeli ve onu bir eylemlilik alanına dönüştürmeliyiz. 
Varlığın titreşen kuvvetler olduğunu kabul ettiğimizde, aslında işimizin nesnelerle değil bu kuvvet ilişkilerini yakalamakla ya da işlemekle ilgili olduğunu biliriz. Bugün kuvvet akışlarının algısına bizi doğrudan açan arayüz, kodlama sistemleridir. İmajlar kodlama sistemlerinin ürünü değildir ama beynin ötesinde işlemek için onların ara yüzüne ihtiyaç duyarlar. Simülasyon teknolojilerini de içine alacak şekilde bu çağda düşünce, "ya hep, ya hiç" mantığıyla ifadesini bulacak olan bir ara yüze kavuşmuştur. Bu dilin felsefi anlamı ve politik etkileri üzerine düşünmeye bir yerinden başlamamız gerekir. Hür fikirlerin hür tartışma ortamlarında yeşerebileceğinin farkında olan felsefeciler, kullandıkları teknolojiye hakim oldukları kadar, onun koşulları hakkında da politik bir duruşa sahip olabilirler. Felsefenin özgür yazılımla ortak bir zeminde buluşması gerektiğinin farkına varabiliriz. Özgür yazılıma göre özgürlük, yazılımı çalıştırma, kopyalama, dağıtma, üzerinde çalışma, değiştirme ve geliştirme serbestisiyle belirlenir. Bu bağlamda, felsefeciler, alfabeden oldukça farklı olan kodlama sisteminin düşünce üzerindeki etkisini ve bu etkinin kapsamını araştırma; ikinci olarak da, kaynak kodların kapitalist kapma aygıtından kurtarmaya dönük temel iki hedefi yerine getirmek için araçlar geliştirebilirler. Fakat bu hedefleri yerine getirebilmek için öncelikle, teknolojinin düşüncenin ürünü olmasının yanında aynı zamanda düşünceyi kökten değiştirdiğini de kabul etmek gerekir. Şimdi araştırılması öncelikli olan olgu, yazı gibi bir uzamsallaştırarak sabitleyen bir temsil sistemi olmadan video gibi doğrudan gerçekliğin imajlarıyla bağ kurmamızı sağlayan bir teknolojiyle ne yapacağımızdır.

Videodüşünürler, kameranın ve imaj işleme sistemlerinin, algıyı ve düşünceyi insan bedeninin sınırlarından kurtardığının farkındadır. Bedenler arası kuvvet geçişlerinin hareketine artık bir öznenin gözünün sahipleniciliği olmadan erişebiliriz. Bedenlerin oluşuna, onların yeğinliklerini ve cisimsiz ilişkilerini kapmaya muktedir bir aygıtla doğrudan açılabiliriz. Bu bize kelimelerin aracılığı ve temsil sistemlerinin yönlendirici koşulları olmadan oluşu tanıma ve onun üzerinde eyleme olanağı kazandırır. Düşünceyi, bilincin kontrollü eyleminin ötesine taşır ve bilinçdışı olanı düşüncenin maddesine bizzat taşır. Psikolojik bir öznenin işlevine indirgenemeyecek bir duyumsanırın (görülebilir) kapılarını aralar. Bu manevra bizi, çoktandır algının ve düşüncenin kapitalist üretim aygıtına dönüşmüş bir temsil üretme makinesi olan sinemaya karşı bir hareketin içine itecektir. Sinemanın doğasını devrimci bir değişikliğe uğratmak, ancak video gibi doğası gereği imajı sinematografik dilin emperyalizminden kurtarma olanağıyla doğmuş bir teknoloji tarafından başarılabilir. Sinemayı temsilin elinden alabilmenin yolu önce onu aşmakla mümkündür. Sinema endüstrisinin kapitalist antidevrimci etkisinin nasıl aşılacağına dair Dziga Vertov'un bir dizi önerisini hatırlatmak yerinde olacaktır (Vertov, 2007). Yeni alg1 ve düşünce biçimlerinin tüm virtüel olanakları sinema endüstrisi ile birlikte "izleyici-yönetmen" ilişkisine indirgenir. Endüstrinin, oyuncuları, senaryoları, stüdyoları, yönetmenleri ile birlikte tüm sine-dram unsurları, temsilin yeni ifade biçimlerini ele geçirmesinin ürünüdür. Sine-duyarlılık, yeni teknolojilerin meydana getirdiği yeni bedenselliğin ve oluşum halindeki yeni makinesel öznelliğin keşfedilmesi için imajları temsilin elinden almak gerektiğine inanmaktır. Çünkü, sinemadaki iş bölümü ve beraberinde getirdiği imajların temsilin hiyerarşisine tabi tutulması, zamanın serbest kuvvet akışlarını ve bunların insandaki kuvvetlerle birleşimini duyumsamayı ve düşünmeyi engelleyen perdeler örerler. İmajların devrimi, onların belirli bir zamanın ve mekanın sınırlarından kurtulması, oluşun bütün açllarıyla duyumsanabildiği çoklu bir perspektife ulaşmakla mümkündür. Sinegöz zamanın mikroskobu ve teleskobudur, matbaası değil. Sine-göz, bambaşka yerlerden bambaşka zamanlardan imajların, bambaşka hareketlerin ilişkilenmesine izin verecek montaj sayesinde, insan duyularının sınırlarını aşar ve üzerine kurulduğu aralığı duygulanımsal bir 
kuvvet ve düşünme yetisiyle doldurur. Eğer dünyayı değiştirecek "olay üretmek" istiyorsak, "sine-gözlemler" ve "sine-analizler" üreten "kino-gözlemciler" olmalıyı.

Dünyamızı ve zihinlerimizi doldurup zapt eden imajların incelemesine girişmek için beklemeye gerek yoktur. Kino-gözlemci olmayı video sanatçıları başarıyor gibi görünüyor, neden felsefeciler de yaşamın ritmini doğrudan imajla yakalamanın yollarını icat etmeye girişmesin? Felsefeciler kitlelerin afyonu TV aygıtını karşıdan bir izleyicisi olarak mı eleştirmekle yetinecekler? Karakutunun içine girerek gösterinin değil yazılımın diliyle konuşmak için neyi bekliyorlar? Dilbilimsel semiyolojilerin filtresinden geçmeksizin, doğrudan izleyicinin beynine aktarılan düşünceler üzerine çalışmayı, sözün aracılığı olmadan ekrandan izleyicinin beynine akmayı denemek için bir engelimiz var mı? Ekran, beyinden beyine, bedenden bedene düşünsel aktarımın bir yolunu sunuyor ve biz bu akıcılık karşısında dilimiz tutulmuş bakıyoruz! Video bize, yalnızca insan gözünün gördüğünün doğru olduğuna dair yıkılmaz görünen tabunun yıkılabileceğini gösteriyor. Bunu bize gösteren yine insanın kendi düşüncesinin ürünü ve onun uzantısı olan kendi yarattığı bir teknoloji. Kendi maddeselliği üzerine bile araştırılmayı hak eden bir teknoloji.

Sosyal bilimler 1960'lardan bu yana, duyusal malzemeyi bilgi üretim sürecine dahil ederek, bilginin bedenliliği içermesinin epistemolojik ve etik sonuçlarını deneyimledi. Felsefe, bedenleri düşüncesine katmamak için neden direniyor? Bedenler, algılam aracılığıyla düşünmek, neden felsefeye uzak görünüyor? Felsefeciler, filmler hakkında düşünmeyi benimsemiş görünüyorlar da, filmler aracılığılyla düşünmek neden onlara yabancı kalıyor? Duyulur ve duygulanımsal olan üzerine konuşmaya devam etmemize rağmen, onlarla iş yapmayı reddetmemeliyiz. Düşüncenin koşulları ve kökensel oluşumu hakkında düşünmeyen ve yarattığ1 teknolojik uzantıların kendi evrimindeki etkisini hesaba katmayan düşünce, düşüncenin eylem yaratmaya muktedir olmayan cılız bir ifadesi olarak kalmaya mahkum olacaktır.

\footnotetext{
' Bu ifade Deleuze'ün Cinema II: Time Image kitabında "zaman kristali” ifadesiyle yankılanır. Deleuze, Cinema I kitabında "zaman kristali" tabirini, bu ifadenin mimarı olan Guattari'den (2011) aldığını belirtir (Deleuze, 2005: 82,92). Deleuze "zaman kristali" tabiriyle, Bergson'un zaman felsefesine sırtını dayayarak, zamanı geçmiş, gelecek ve şimdinin lineer bir çizgi üzerinde sıralanmasıyla değil ama gelecek ve geçmiş olarak iki asimetrik yönün birleşimi olarak anladığını ifade etmek için kullanmıştır. Buna göre, zaman kristali, edimsel imgeyle (mevcut imge), gücül imgenin (potansiyel olarak eş zamanlı var olan ancak geçmişte yer edinen imge) üst üste binmesiyle ortaya çıar (Deleuze, 2005:81-2). Örneğin, hylo-sign ya da ayna-imgeler, filmdeki zamanı sekteye uğratırlar ve öncelik sonralık akışında kesintiye neden olurlar. Böylece, ortaya edimsel olanla gücül olanın aynı andalığı durumu çıkar. İşte bu aynı andalık imgesine "kristal-imge" denir (Deleuze, 2005:81). Hatırlama-imgeleri, rüya-imgeleri ve dünyaimgeleri yine bu türden imgelerdir (Deleuze, 2005:69). Edimsel optik imge kendi gücül imgesiyle, küçük içsel bir devrede kristalize olduğunda ortaya çıkarlar (Deleuze, 2005:69). Ancak Deleuze, kristal-imgenin zamanın kendisi olmadığını söyler: "kristal-imge zamanın kendisi değildir, ancak biz zamanı kristal içinde görürüz. Kronolojik olmayan zamanın ebedi kuruluşunu kristalde görürüz" (Deleuze, 2005:81). Bu noktada Deleuze'ün bahsettiği kristal-imge zamanın kendisi değil, zamanın sinematografik yapı içinde olabildiğince doğrudan göründüğü halidir. Diğer yandan Lazzarato, doğrudan enerji olarak sürenin/saf zamanın maddeselleşmesi anlamında zamanın kristalleşmesi terimini kullanır. Lazzarato ve Deleuze'ün aynı kaynaktan yani Bergson' dan yararlanması ve ikisinin de edimsel-gücül ayrımı ve birleşimi üzerine kurulu bir zaman anlayışını benimsemesinden kaynaklı, genel olarak imgeye dair yaklaşımlarında temel bir paralellik olduğu söylenebilir. Deleuze kristal-zaman ile zamanın imgeler aracılığıyla bir görünüm kazanmasından, Lazzarato ise zamanın kendisinin (elektromanyetik dalga), kodlama aracılığıyla kristalleşmesinden yani maddesel bir varlık kazanmasından bahseder. Deleuze daha ziyade analog imge rejiminin ürünü olan film hakkında konuşurken, Lazzarato ise dijital imgenin ontolojisi üzerine düşünür. Ancak, virtüel olanın maddeselleşerek edimsel hale gelmesi bakımından zamanın kristalleşmesi ya da kristal imge nitelendirmeleri birbiriyle yankılanır.
} 
ii Guattari Kapitalizm ve Şizofreni serisinin son kitabı $A$ thousand Plateaus'un (1987) yazılmasından bir kaç yıl önce yazdığı Machinic Unconscious (1979) kitabında, sermayeyi sadece bir ekonomik kategori, göstergeleri de yalnızca ideoloji meselesi olmaktan uzak anlamanın yolunu açan bir tespitte bulunarak, sermayenin öznellik üretimi de dahil üretimin bütün biçimlerini şekillendiren semiyotik bir işlemci olduğunu söyler. Sonrasında bu fikir A thousand Plateaus'da Deleuze'le birlikte daha geniş bir analize dönüşür. Buna göre kapitalist semiyotik, ya gösteren semiyotikler aracllı̆̆ıyla temsiller ve imleme süreçlerini denetler, e.g. ulusal diller, ve böylece üretim ağındaki failleri ve faillik konumlarını yaratır, ya da göstermeyen semiyotikler aracılığıyla, e.g. para, imge, ses, bilgi, işlev bilimsel diyagram vb. işleyerek sembolik ya da gösteren bir denetim zinciri yerine daha ziyade makinesel bir bağlantılandırma işlevi yaratırlar (Lazzarato, 2015). Birincisi, toplumsal tabi kılma makinesini devreye sokar ve özneye tayin edilen roller sayesinde sosyo-ekonomik denetim ağını aktif etkisi altında tutar; ikincisi ise, Guattari'nin "makinesel kölelik" dediği denetim biçimini devreye sokarak, kişi-öncesi algı, arzulama üretimi, duygulamları kapar ve harekete geçirir (Guattari, 1979). Yazı teknolojisi ve bu teknolojinin ürünü olan kodlama sistemleri, yalnızca gösteren semiyotikler sayesinde söylemler yaratma işleviyle değil, daha ziyade sistemi işler kılmaya hizmet ederek, hem toplumsal tabi kılma operasyonuna hem de makinesel köleliğin aktif varlığına katkıda bulunur. Bir yandan toplumsal ve teknolojik makinelerin parçası haline getirerek, öznellikleri işlevler haline getirirler; diğer yandan da, temsiller ve anlamlar yaratarak toplumsal makineye tabi kılarlar. Yazı teknolojisi bu anlamda "karma semiyotikle" işler (Guattari, 2011: $55,108)$.

\section{Kaynakça}

Artaud, Antonin, (2002). Tanrı Yargııının İşini Bitirmek İçin. (çev. Mehmet Bağış). Sel Yayıncılık.

Baker, Ulus, (2015). Kanaatlerden İmajlara: Duygular Sosyolojisine Doğru. (çev. Harun Abuşoğlu). Birikim Yayınları.

Bergson, Henri, (2005). Matter and Memory, (Çev. Nancy Margaret Paul ve Scott Palmer). New York: Zone Books. (1988).

Bergson, Henri, (2007). Madde ve Bellek, (çev. Işık Ergüden). Dost Yayınları. (1988).

Bergson, Henri, (1913). Time and Free Will. (Çev. F. L. Pogson). New York: Dover Publications, Inc.

Clark, Andy ve Chalmers David J. (1998). “The extended mind". Analysis. 58 (1): 7-19.

Debord, Guy, (2016). Gösteri Toplumu. (Çev. Okşan Taşkent, Ayşen Ekmekçi). Ayrıntı Yayınları.

Deleuze, Gilles ve Guattari, Felix. (1987). A Thousand Plateaus: Capitalism and Schizophrenia. (Çev. Brian Massumi). London: the University of Minnesota Press. (1980).

Deleuze, Gilles ve Guattari, Felix. (1983). Anti-Oedipus: Capitalism and Schizophrenia. (Çev. Robert Hurley, Mark Seem, and Helen R. Lane). London: the University of Minnesota Press. (1972).

Deleuze, Gilles, (1992). Cinema 1: The Movement-image, (Çev. Hugh Tomlinson, Barbara Habberjam). London: The Athlone Press.

Deleuze, Gilles, (2005). Cinema 2: The Time-image, (Çev. Hugh Tomlinson, Robert Galeta). London: Continuum.

Derrida, Jacques, (1997). Of Grammatology. (Çev. Gayatri Chakravorty Spivak). Baltimore: The Johns Hopkins University Press.

Fodor, Jerry A., (1975). The Language of Thought, New York: Thomas Y. Crowell. 
Foucault, Micheal, (2014). Sonsuza Giden Dil. (Çev. Işık Ergüden). Ayrıntı Yayınları.

Guattari, Felix, (2011). The Machinic Unconscious: Essays In Schizoanalysis, (çev. Taylor Adkins). Los Angeles: Semiotext(e). (1979).

Lazzarato, Maurizio, (2015). Göstergeler ve Makineler. (çev. Münevver Çelik). Otonom Yayıncılık.

Lazzarato, Maurizio, (2016). Videofelsefe. (Çev. Şule Çiltaş Solmaz). Otonom Yayıncılık.

Marks, Karl, (1976). Capital Vol.I: The Process of Production of Capital. (Çev. Samuel Moore and Edward Aveling). Moscow: Progress Publishers.

McLuhan, Marshall ve Lewis H. Lapham, (1994). Understanding Media: The extensions of man, The MIT Press.

Ong, J. Walter, (1991). Sözlü ve Yazılı Kültür. (Çev. Sema Postacıŏlu Banon). Metis Yayınları. Vertov, Dziga, (2007). Sine-Göz. (Çev. Ahmet Ergenç). Agora Kitaplığı. 